Shaulder to knee. Lessons learnt

Professar Peter F.M. Choung

MD FRACS

University of Melbourne, Department of Surgery, St. Vincent's Hospital Melbourne

pchoung包unimelb.edu.au

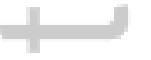

Post-surgical problems can be distressing to patients and surgeons alike. Sometimes the solutions are more complex than what was required to deal with the initial problem. Knee stiffness is one of thase bugbears. Almost I0\% of all knee replacements are assaciated with post-operative knee stiffness. There are many causes for this and some have far greater long term implications than others, for example, infection, prosthesis mal-alignment or aversizing of components. Thankfully, these farm the minority. For the most part, knee stiffness can be dealt with through a combination of motion exercises, pain management and patience. With diligence, stiffness does improve. However, not all patients tolerate this combination well, and face a range of surgeries with escalation of violence, from simple manipulation under anaesthesia to full revision of implants. Even manipulation under anaesthesia may not be straight forward with femoral fractures being reported. Whatever the solution may be, desperation is something both patient and surgean will feel.

A contraversial issue is deciding when to intervene with a stiff knee. Harder still is what to do when stiffness is still a problem many months after surgery. In today's age, under the constant scrutiny of funders, institutions, and surgical peers amongst others, surgenns are aware of the problems of aver servicing, iatrogenic problems, and working in an evidence free zone. Managing the stiff knee after tatal joint replacement is one of thase chestnuts.

Formby et al', have reported a simple appraach that leverages the established experience with frozen shoulders, namely, hydradilatation. In frozen shoulders, the painful restricted range of motion is relieved by dilating the shoulder joint with sterile fluid. The fluid serves to "tear" joint adhesions in all directions as the fluid ballouns outward stressing all parts of the joint capsule. This procedure can be done both in theatre or in a radiology suite. The latter is mare common.

Interestingly, hydradilatation of the knee, per se, has not been a specific option despite the successes in the shoulder. Usually any farm of hydradilatation is performed in conjunction with arthroscopy and the impact of the distention is missed. Framby et al., reparts a small series fram a wider and longer experience showing that up to 20 degrees of additional range can be achieved and maintained following hydrodilatation alone. As in the shoulder, done as a day procedure, under light sedation and without the need far operative instrumentation, hydradilatation of the knee may be a simple, safe, resourceful and costeffective means of treating knee stiffness after total joint replacement.

Sometimes the simplest things can be the sweetest.

\title{
Reference List
}

1. Formby PM, Donohue MA. Cannovat CJ, Caulfield JP. Hydraulic distension of the knee: A novel treatment for arthrofibrosis after total knee replacement (case series). ANZJSurg 2016;86:480-482

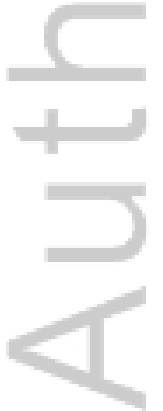

This is the author manuscript accepted for publication and has undergone full peer review but has not been through the copyediting, typesetting, pagination and proofreading process, which may lead to differences between this version and the Version of Record. Please cite this article as doi: $10.1111 /$ ans.13968 


\section{University Library}

\section{- M M I N E R VA A gateway to Melbourne's research publications}

Minerva Access is the Institutional Repository of The University of Melbourne

Author/s:

Choong, PFM

Title:

Shoulder to knee: lessons learnt

Date:

2017-05-01

Citation:

Choong, P. F. M. (2017). Shoulder to knee: lessons learnt. ANZ JOURNAL OF SURGERY, 87 (5), pp.325-325. https://doi.org/10.1111/ans.13968.

Persistent Link:

http://hdl.handle.net/11343/292830 